\title{
CORPORATE WEBSITE CONTENT RELATED TO DISABILITY IN THE TOP 50 FORTUNE FIRMS IN TURKEY
}

\author{
Lect. PhD. Murat NAZLI \\ Yasar University, Faculty of Business, İzmir, Turkey (nazli.murat@gmail.com) \\ Asst. Prof. Dr. Evla MUTLU \\ Antalya Bilim University, College of Tourism, Antalya, Turkey (eevlamutlu@gmail.com)
}

\begin{abstract}
As a result of worldwide increased awareness in disability, organizations in Turkey are also assumed to reconsider their values, norms and behaviors accordingly. Considering the intention of maintaining legitimacy in especially high revenue firms, this study aims to reveal similarities and differences about disability disclosure of top 50 Fortune firms'websites in Turkey. Website contents are analyzed via content analysis. Results indicate that firms give emphasis on 'physical conditions in facilities', 'education of people with disabilities and employees', 'products', 'requirements to get services' and 'donations'. In some industries firms share similar contents though differences are more than similarities in overall. Firms' poor application of disability employment related legislations are also discussed in results. Accordingly this study reveals current understanding while emphasizing potential improvements.
\end{abstract}

Keywords: Disability, Website Content, Institutionalization, Stakeholder.

\section{TÜRKIYE'DEKI TOP 50 FORTUNE FİRMALARININ KURUMSAL WEBSITELERINNDE ENGELLİ İÇERİĞİ}

\begin{abstract}
ÖZET
Engellilik konusunda dünya genelinde artan farkındalık neticesinde, Türkiye'deki örgütlerin değerlerini, normlarını ve davranışlarını bu doğrultuda gözden geçirdikleri varsayllmaktadır. Bu çalışmada meşruiyetini koruma niyetinde olan, özellikle de yüksek gelirli firmalar dikkate alınarak, Türkiye'nin en iyi 50 Fortune firmasının web sitelerinin engelli kavramına ilişkin içeriğinde benzerlik ve farklılıkları ortaya çıkarmak amaçlanmıştır. Web sitesi içerikleri, içerik analizi kullanılarak analiz edilmiştir. Sonuçlara bakıldı ̆̆ında, firmalar 'tesislerdeki fiziksel koşullar', 'engelli ve çalışan eğitimi', 'ürünler', 'hizmet alabilme koşullarl' ve 'bă̆ısslar' konularına ă̆ırlık vermişlerdir. Bazı sektörlerde firma web sitelerinin benzer içerikleri paylaştı̆̆ görülmektedir, ancak genel olarak farklılıklar benzerliklerden fazladır. Firmaların engellilere yönelik yasal zorunlulukları uygulamadaki yetersizliği de sonuçlarda tartışılmıştır. Bu açıdan, yapılan çalışma mevcut anlayışı ortaya koyarken, olası iyileştirme alanlarını da vurgulamaktadır.
\end{abstract}

Anahtar Kelimeler: Engelli, Web Sitesi İçeriği, Kurumsallaşma, Paydaş. 


\section{Introduction}

Globally increasing awareness about the social and economic issues related to people with disabilities, also affects the individuals, governmental and non-governmental corporations in Turkey. The establishment of governmental bodies and regulations, precision of commercial corporations and the support of civil society, lead the evolvement of perspectives about disabilities. As Moore (2013) emphasized that it is pivotal to address certain issues as much as possible for the missing voices or seldom heard voices of disabled people caught up in conflict and crisis. In this sense, firms are expected to increase their awareness about disability related issues.

The way in which companies increase their awareness about disabled people is an issue to be discussed. Some researchers explain this social disclosure of the firms through legitimacy theory which is strongly related to institutionalization. As DiMaggio and Powell (1983: 152) indicated, through institutionalization theory, isomorphic change occurs in "organizations tend to model themselves after similar organizations in their field that they perceive to be more legitimate or successful'. So firms are assumed to develop disability related disclosure similar to each other. In order to predict isomorphism, organizations can be analyzed for similar structure, behavior and process patterns (DiMaggio \& Powell, 1983: 154).

Link between isomorphism and legitimacy is also indicated by researchers (DiMaggio \& Powell, 1983; Suchman, 1995). Deephouse (1996) supported this relationship with an experimental research, where results reveal the positive relationship between isomorphism and legitimacy regardless of the firm age, size and performance.

Legitimacy theory is also linked to social responsibility in several studies. Patten (1991) reveals that high public pressure is effective on firm's social disclosures, but profitability is not. Though according to De Villiers and Alexander (2014), large firms are recognized to give more social information than small firms and this applies both in annual reports and corporate websites. Besides as an effect of legitimacy theory, higher visibility is examined to result in higher interest in developing the corporate image through social responsibility (Branco \& Rodrigues, 2006). Similarly, Quevedo-Puente et al. (2007: 66) indicate that "corporate social performance describes the legitimacy of the firm's behavior towards its stakeholders by the standards of its institutional context at a particular moment in time". As seen, stakeholder theory is also related to this process as an empowering factor.

People with disabilities are employees, customers, partners of these firms, which indicate stakeholder theory. Freeman (1984) defines stakeholder as "individuals or groups influencing and/or influenced by success of organizations." In this approach, managers apply, design processes that satisfy all stakeholders of the organization. The purpose of stakeholder approach is to manage the relation of shareholders, employees, suppliers, customers, communities and their interests in long-run for the success of the organization (Harrison \& Freeman, 1999). In this sense, employees are one of key stakeholders who should have a voice in corporate governance mechanism (Blair, 2004). So, with the support of stakeholder theory, firms are assumed to shape their values and norms similarly, which will result in similar activities, disclosures about disability. 
Between 2007 and February 2017, considering the academic research related with corporate websites and disabilities in relation with the stakeholder theory, studies are mainly formed in the frame of corporate social responsibility such as projects about unemployed groups, people in need of help, communication with minority groups, minority development and disability in several ways. These studies are not directly related with the topic of disability. Only a couple studies exist and directly related with a disability such as web accessibility for the blind (Frank, 2008) and language use in college athletic department websites with people with disabilities (Pate et al., 2014).

As a fact of maintaining legitimacy through a high visual and so isomorphic environment, firms are assumed to address similar topics related to disability. In order to analyze this issue, corporate websites of top 50 Fortune firms are evaluated, since these are visual, high profit firms, aiming to satisfy all stakeholders. Besides, no research has investigated for Turkey in order to understand the attitude and actions of high revenue firms related to disability.

Accordingly, in the following sections, definition and types of people with disability is addressed in a general meaning and people with disabilities in Turkey are analyzed through the statistical data. After, the corporate website content related literature is discussed.

\section{People With Disabilities in Turkey}

Analyzing the legislations about employment of disabilities, as indicated by Tas and Bozyaka (2012), European Union related improvements took place in "the obligation of employer to provide proper workplace conditions" and "encouragement of people with disability and disadvantages to workforce" topics. In regulatory manner, the law about people with disabilities is published in 2005 and aims to "encourage, procure people with disabilities to facilitate the fundamental rights and freedoms, provide full and active participation to social life by empowering natural-born honor, and to ensure to take steps for necessary arrangement to avoid the disability." as indicated in the legislation about disabilities (Engelliler Hakkında Kanun, 2005). Covering a variety of issues, regulations are related to care centers, employment, education and so forth (Republic of Turkey Ministry of Family and Social Policy, 2014). Such as, this paper focused on these issues, but through commercial corporations' perspective.

Besides, the efforts in Turkey are quite inadequate from some points. For instance, The Americans with Disabilities Act (ADA) of 1990 eliminate the discrimination of individuals with disabilities in employment, public services, public accommodations and telecommunications (Podlas, 2015; USDL, n.d.). Some researchers claim that neither ADA nor Disability Discrimination Act (DDA) in Britain do not help with the employment of people with disability, related to lack of financial support, uncertainty in litigation costs and low level of awareness about the Acts (Bell \& Heitmueller, 2009). In Turkey, there is no such act that is effective across the country.

The main governmental body related to people with disabilities is General Directorate of Services for People with Disabilities and Elderly People which is a subunit of Republic of Turkey Ministry of Family and Social Policies. Non-governmental and nonprofit associations are such as Foundation of Disability, Foundation of Physical Disability, Sports Federation of People with Physical Disabilities, Confederation of Disability study on increasing awareness, gaining financial support for educational and social activities of people with disabilities. 
According to the statistics of the situation of disability in Turkey, the most recent statistics about the percentage of people with disabilities is $22.1 \%$ (TUIK, 2015) according to the census in 2011, which is the most recent statistical data pointing the number of people with disabilities.

The governmental funding of people with disabilities is recognized to increase between 2002 and 2015 which also indicates the number of disabilities received funding. According to the statistics of funding receiving disabilities, the number of people with disabilities has been increasing since 2002 (Figure 1). However the increase in the number of individuals having disability rate of $70 \%$ appears to be increasing at a higher rate, but less consistent with respect to the increase in disability between the rates of $40-60 \%$.

In addition, funding for the people with the disability rate of $70 \%$ and more, have increased 18 times from 2002 to 2015, reaching to $4934 \mathrm{TL} /$ individual. Also, funding for the people with disability rate between $40-69 \%$, is increased by 12 times within the same period of time, reaching to $3372 \mathrm{TL} /$ individual in 2015. The differences between funds are understandable, since people with higher disability rates need more support.

Furthermore, according to the information obtained in the 2011 census, when the distribution of disabled people according to their age groups is examined, the possibility of disability increases with age increase in both men and women (General Directorate of Services for People with Disabilities and Elderly People, 2016).

Figure 1: Number of Governmental Funding Receiving Disabilities Between 2002 and 2015 in Turkey

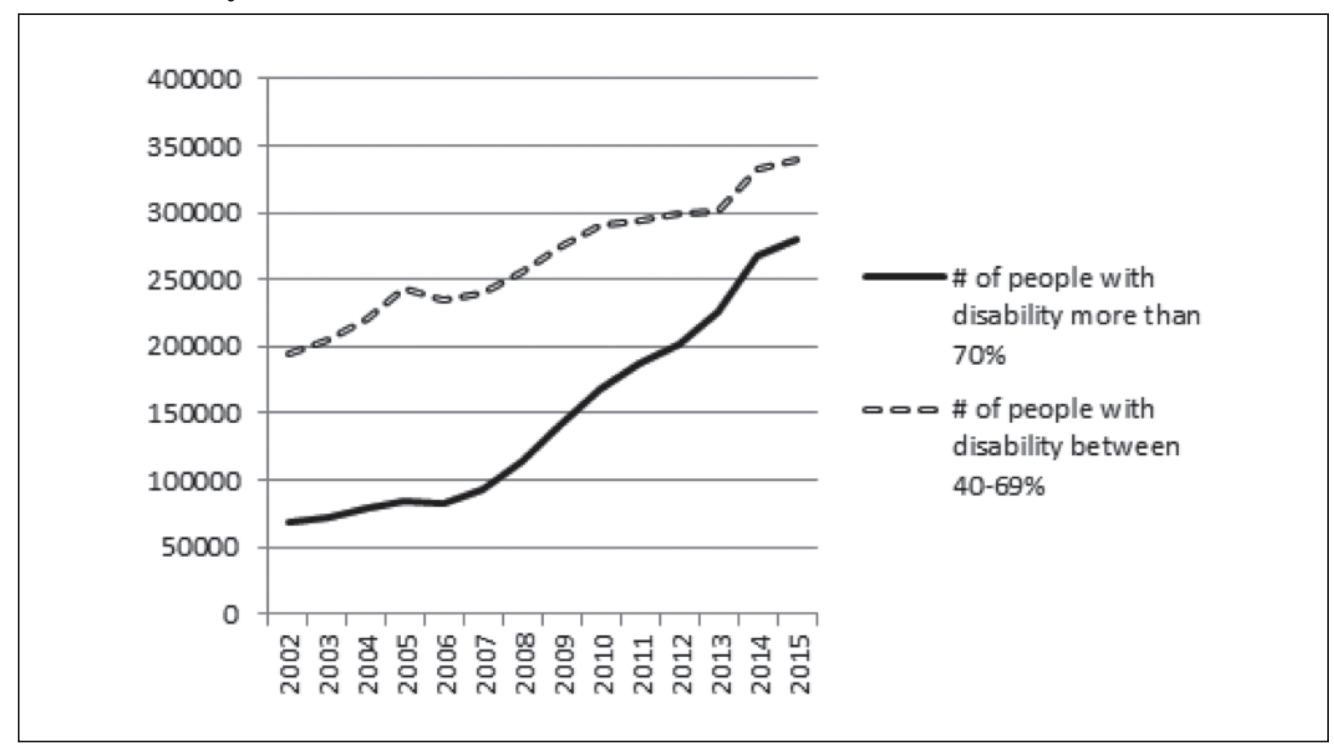

Source: Adapted from General Directorate of Services for People With Disabilities and Elderly People (2016). 
Considering the disability in education, the number of disabled students seems to increase almost every year between 2002 and 2015 (Figure 2). It is also recognized that the number of schools for people with disability has displayed a very low increase since 2013 . However, it would be useful to observe changes in the capacities of the schools to come to a conclusion.

When the employment of disabled individuals is examined, within the scope of Article 30 of Labor Law No. 4857, employers are obliged to employ a certain number of people (4\% of total employees for public sector; $3 \%$ of total employees for private sector) with disabilities where the total employment number is 50 or above. The legislation also allows firms to employ disabled people in jobs suitable for their occupational, physical and mental conditions. According to the statistics related to the employment of disabled people in Turkey between 2002 and 2015, employment in the public sector seems to be low, as the total workforce in this area is low (Figure 3). Fluctuations in the graph may be related to economic factors, total employment rates, governmental policies and needs further examination.

According to the report of General Directorate of Services for People with Disabilities and Elderly People (2016) of Turkey, employment of people with disability is lower than the number restricted in legislation. Work Legislation no 4857 forces the non-governmental firms having more than 50 employees, to employ $3 \%$ people with disability. This percentage increases to $4 \%$ for governmental firms. According to the non-governmental firms which have 88190 employees with disability where it is obliged to be 104790 until April 2016 (General Directorate of Services for People with Disabilities and Elderly People, 2016). Contrarily, governmental

Figure 2: Number of Schools for People with Disabilities, Between 2002 and 2015 in Turkey

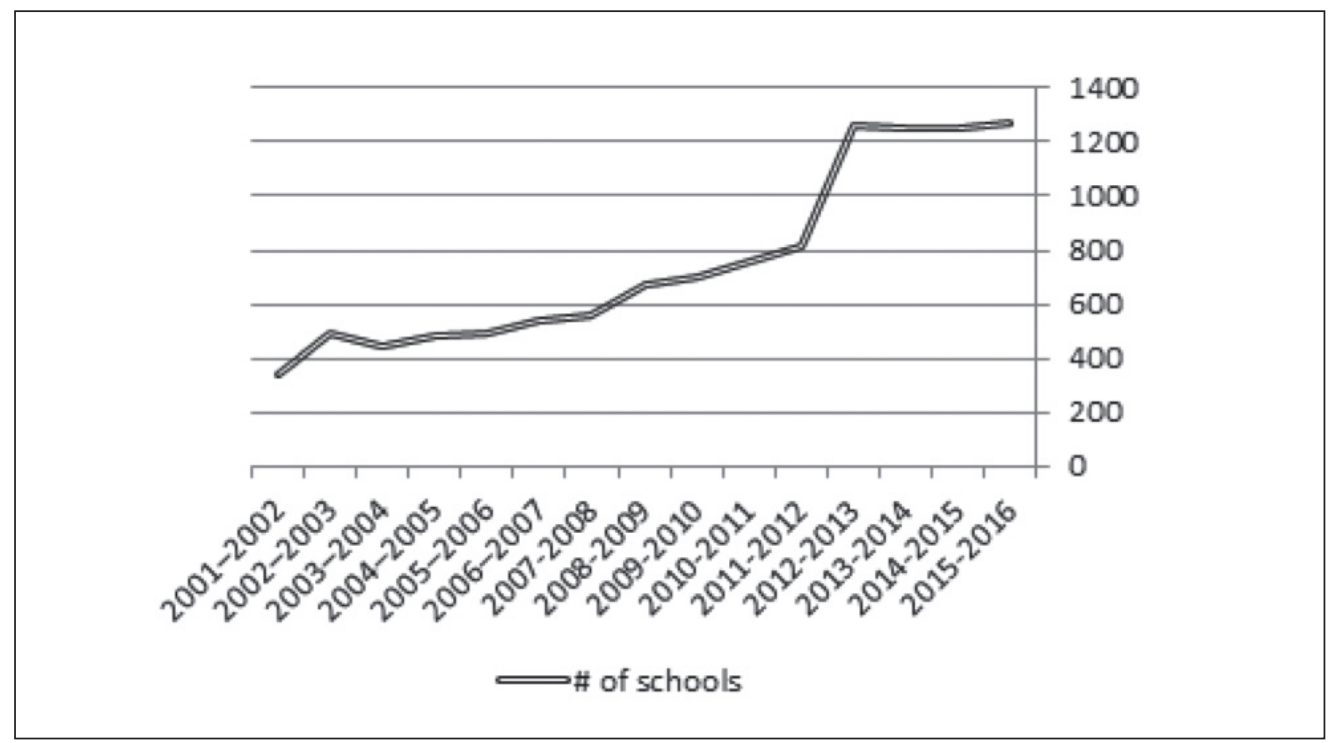

Source: Adapted from General Directorate of Services for People With Disabilities and Elderly People (2016). 
bodies employ more than $4 \%$. Statistics indicate that non-governmental organizations do not employ people with disabilities fair enough, in general. The employment of the people with disability with the appropriate number of legal obligations is not actualized in some cities. According to the information on disability employment published monthly by İşkur (2015), on average $16 \%$ of the applicants are employed according to different types of disability in 2015 .

\section{Corporate Website Content About Disability}

The use of the internet by people with disabilities has been studied by various researchers (Bundon \& Clarke, 2015; Goggin \& Newell, 2003). As indicated by Ellis and Kent (2011: 1), inventor of the World Wide Web, Tim Berners-Lee underline the importance of accessibility to internet "by everyone regardless of disability". The widespread use of internet in the society may be recognized as an advantage for people with disabilities in terms of information accessibility, but it requires high-cost software and hardware tools (Goggin \& Newell, 2003).

Internet can be used by people with disabilities for several purposes such as; gaining and publishing information, developing and maintaining networks, peer mentoring (Seale, 2007). On the other hand, it is a challenging issue that what type of facilities the websites require for the disabled to reach and use. For instance, Web 2.0 applications are indicated to "pose both increased opportunities and greater challenges for people with disability" (Ellis \& Kent, 2011: 132). There is a standardization of ADA for service facilities, though it does not cover website requirements and discuss the topic in legal contemplation (Podlas, 2015). On the other hand, Web Accessibility Initiative (2017) published how an individual with disabilities facilitates

Figure 3: Employment Number of People With Disabilities in Public and Private Sector, 2002-2015 in Turkey

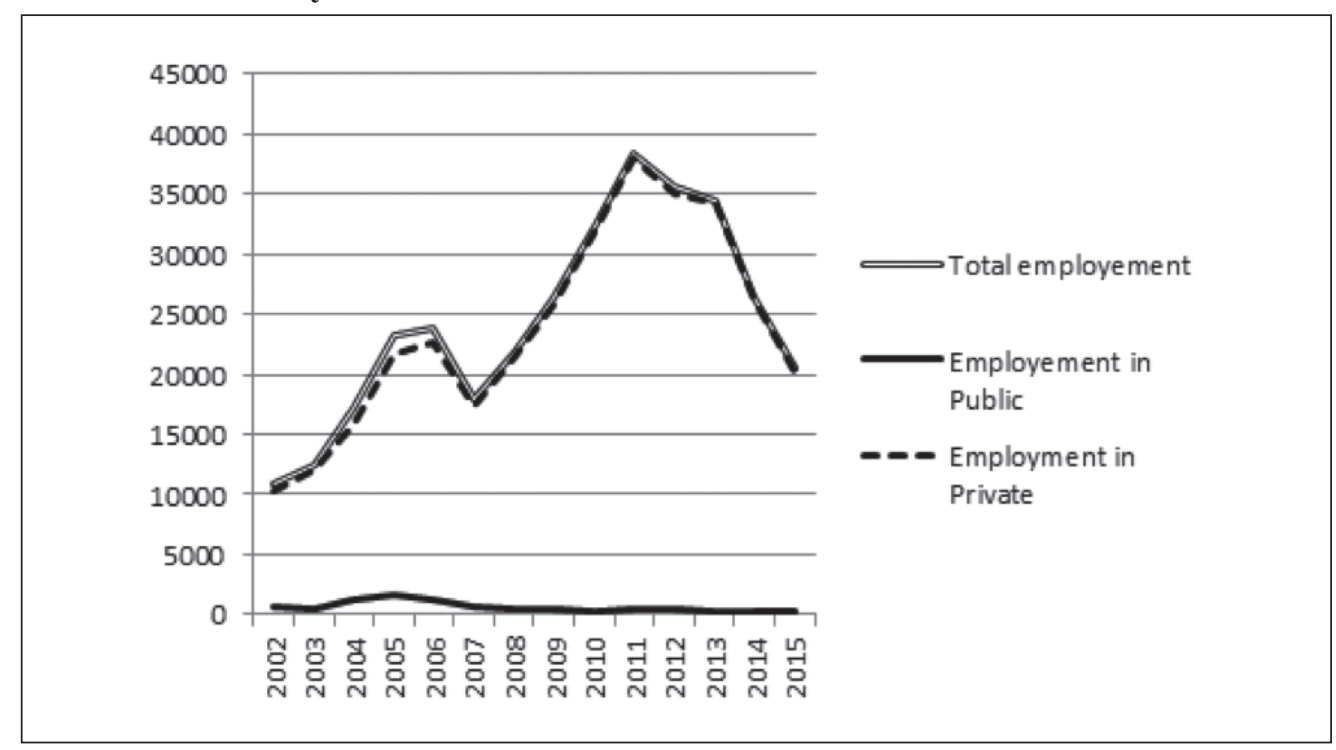

Source: Adapted from General Directorate of Services for People With Disabilities and Elderly People (2016). 
web, including videos, stories, definition of disabilities and accessibility principles. Web Accessibility Initiative (WAI) classifies the disabilities as; auditory, cognitive, neurological, physical, speech, and visual disabilities. Accordingly, there are beneficial principles for website owners to communicate with people with disabilities. According to World Report on Disability (World Health Organization \& The World Bank, 2011), people with disabilities require several services from low to high cost, and further research is necessary to understand people with disabilities in their environments and interactions.

Regarding what type of problems that the disabled individual can come across with when entering the website; "...individuals with vision impairments may be unable to read the text, view images or videos displayed on web technologies; those with hearing impairments may be unable to obtain information from videos lacking captions; those with mobility impairments regarding their hands may be unable to navigate a web technology; those with intellectual impairments may struggle to use portions of web technologies that require timed responses from users" (Briggs \& Saas, 2016).

There are several studies focusing on corporate websites of the Fortune firms, through various perspectives such as; web site usability (Huang \& Cappel, 2012), web based public relations (Kim et al., 2010a), website design (Jones \& DeGrow, 2011; Jones, 2015), website accessibility (Romano, 2002), meeting media/journalist needs (Callison, 2003), characteristics of e-commerce user-interface (Zhao et al., 2006), marketing communications (Perry \& Bodkin, 2002), sustainable information published in websites (Knuz et al., 2014), e-recruiting for human resources (Lee, 2005; Young \& Foot, 2005), home page content and purpose (Liu et al., 1997), privacy policies (Liu \& Arnett, 2002), environmental responsibility (Kim et al., 2010).

Amongst various studies in websites of Fortune firms, there are only a few studies focusing on information about disability. Levy et al. (1992) focuses on the attitudes of Fortune firms' executives on disability employment. Gutierrez and Windsor (2005) also search within the Fortune firms, cover website of corporations but only for home pages. Researchers observe the availability of home pages for people with disabilities, based on regulations of United States of America. Results indicate that "the great majority of organisations do not make it a priority to create websites for the community with special needs".

A detailed analysis is carried by Ball et al. (2005) observed the global Fortune 100 firms, for their diversity policies, defining disability in diversity and employment of people with disabilities. As seen from the literature, websites are beneficial tools to understand the firm's perspective of people with disabilities. For instance, Gabel et al. (2016) searched for the information on corporate website of a university and results indicate "frustrating navigation structures, hidden content and the disengagement of disability from diversity".

This study focuses on the website content of high revenue firms listed in Fortune, content related to disability is analyzed in order to understand the attitudes, approaches and activities of the firms. 


\section{Methodology}

\subsection{Purpose of Research}

The fundamental purpose of this research is to find out similar and different acts of highly visual and large-scale firms in Turkey, which will expose the isomorphic perspectives if exist. Accordingly, analyzing the corporate website content of Fortune firms in Turkey, whether what type of information for disabled stakeholders take place. So that it will be possible to understand the firm perspectives which have net profits ranging from 2.9 to 37.1 billion Turkish Liras in 2015 within various industries and provinces.

\subsection{Research Questions}

Fundamental research questions consist of the shared information of Fortune firms in Turkey for the disabled by investigating their websites (applications, disabled activities or related news etc.) and three main questions are given as follows;

1. What is the perception of the top fifty firms listed in Fortune 2015 in Turkey for the disabled people?

2. What type of information is presented in the organization's websites for the disabled stakeholders?

3. What are the similarities and differences between the website contents? Do the similarities indicate an isomorphic approach?

\subsection{Sample and Method}

Fortune 500 is the list of highest revenue firms, and the first 50 Fortune firm in Turkey is chosen as a sample. The demographics of the sample are listed and corporate websites are visited. Any content related to disability is investigated meticulously. During this process, since the search engine of corporate websites may not be active, Google search engine is used. Turkish word for disability is "engelli" and google search is carried as "engelli site: www xxx. com.tr" which searches for the word "engelli" only in the specified website "www.xxx.com. tr". Google search may also find the pages or documents which are out of date, once shared but not deleted from the website database. This resulted in the duplication of some events, but the most recent data is taken into consideration. For some cases, Google results may direct the researcher to information removed from the website. In such case, if the content is not correct, it would never be added to the websites. In other words, the content removed from the website is valid even if it is not up-to-date. Since the study do not focus on any date range, which is discussed in limitations of the research, out of date content do not harm the perspective of the research.

Besides, the word "engelli" has secondary meanings in Turkish, so the results of google search are analyzed one by one. Only, the links with proper content is taken into account. For some firms, Google search result links were recognized to be irrelevant and duplicate content. Non-Turkish websites are also not evaluated, since contents related to other countries are not a part of this study. Amongst 50 firms, 11 firm websites do not contain any data related to 
disability in Turkish, 7 of 11 firms are foreign-based firms operating in Turkey having multiple websites in different languages.

Relevant content is recorded and then categorized without the guidance of any prior classification template. Categories are reviewed twice and although some of the categories involve common contents, they are not merged since they are recognized to represent a significant set of similarities or differences. Afterwards, the tables are formed based on the number of frequencies of stated expressions in corporate websites. Additionally, website contents are also evaluated for the type of disability referred. Types of disabilities referred are analyzed if the pair of variables is dependent. Chi-square test is carried by $\mathrm{R}$ Studio.

\section{Main Findings}

\subsection{Demographics of the Firms}

As seen in Figure 4, 68\% of the firms are located in Istanbul and 18\% of the firms are in Ankara, the capital city of Turkey.

According to the sectoral distribution, 14\% of the firms are producing and distributing petroleum related products, $10 \%$ are in energy sector (Table 1).

\section{Figure 4: Province of the Firms}

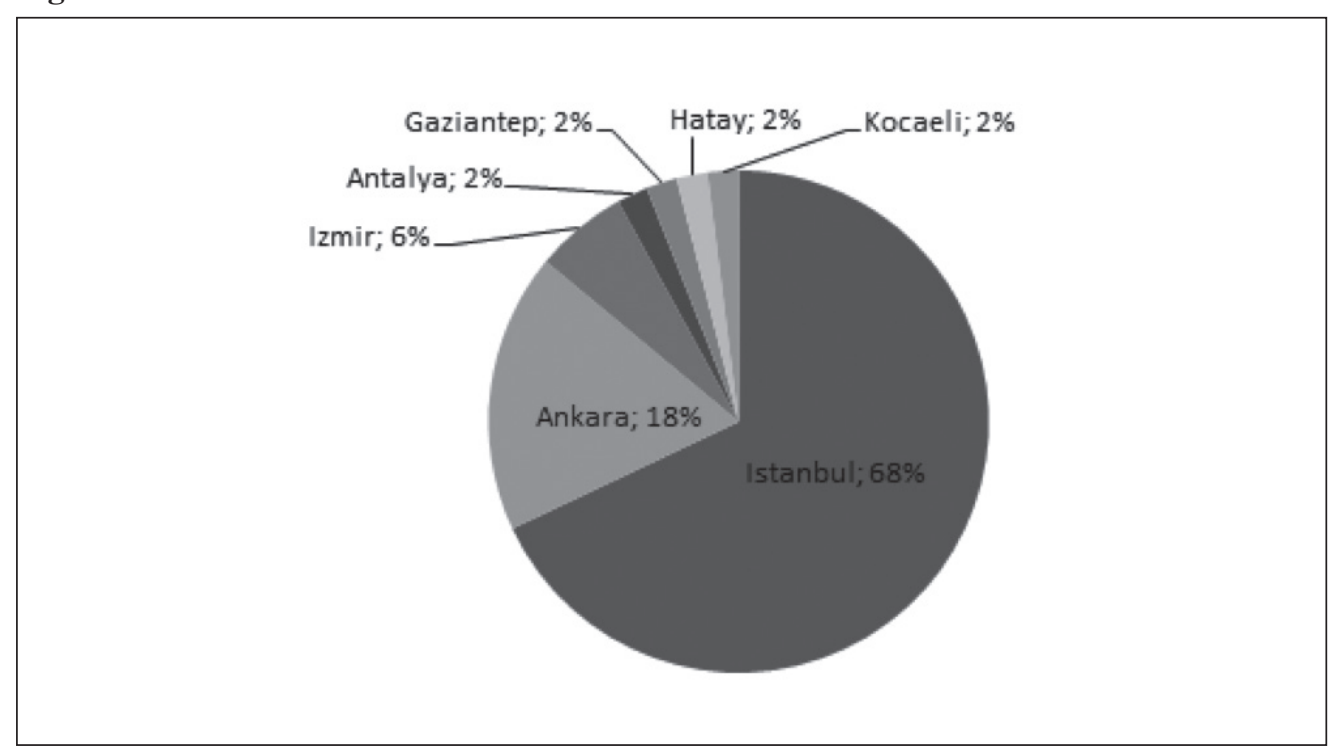


Table 1: Sectoral Distribution of the Firms

\begin{tabular}{lc}
\hline Industry & \# of firms \\
\hline Production and distribution of petroleum and derivatives & 7 \\
\hline Energy & 5 \\
\hline Construction; Retail trade stores & 4 each \\
\hline $\begin{array}{l}\text { Electrical home appliances / Motor vehicle sales and services / Travel and } \\
\text { transportation services }\end{array}$ & 3 each \\
\hline $\begin{array}{l}\text { Chemical substance / Industrial food production / Information and } \\
\text { communication services / Manufacturing and maintenance of vehicles } \\
\text { and equipment / Metal casting and working / Storage, transportation and }\end{array}$ & 2 each \\
\hline $\begin{array}{l}\text { logistics services / Wholesale food, drink and cleaning products } \\
\text { office machines / Industrial food manufacturing / Jewelry / Machine and } \\
\text { equipment / Medical and Medicine / Trade of iron and steel }\end{array}$ & 1 each \\
\hline
\end{tabular}

\subsection{Type of Disability}

According to the content of firm's corporate websites, disability types are referenced as shown in Table 2. Moreover, some firms are recognized to focus on elderly or kids with disabilities. Besides, corporate website of 11 firms does not include the word "disabled". As seen in Table 2,44\% of the firms referred to disability as a general form. For instance, although a firm claims to educate employees to offer a better service for people with disabilities, the type of disability is not specified, so it is classified as "disabilities in general". While the types of disabilities referred indicate the perspectives of the firms, visually impaired people are recognized to be the most frequent type of disability in website content.

Table 2: Types of Disabilities Mentioned in Corporate Websites

\begin{tabular}{lcc}
\hline Type of disability referred & Frequency of item & Firm Percentage \\
\hline Disabilities in general & 22 & 44 \\
\hline Visually impaired & 21 & 42 \\
\hline Walking with disabilities & 19 & 38 \\
\hline Hearing impaired & 15 & 30 \\
\hline Physically impaired & 15 & 30 \\
\hline Mentally impaired & 13 & 26 \\
\hline Motor impaired & 9 & 18 \\
\hline
\end{tabular}

Walking with disabilities is also referred frequently in the corporate websites, though for some cases type of disability is not clearly indicated. For instance, a firm building an elevator for the people with disabilities who cannot use stairs, even if do not use the term "walking with disabilities", type of disability is accepted to be. This distinction is valid only for the "walking with disabilities", but not for the other types of disabilities. 
In order to understand if the relationship between types of disabilities referred, province and sector is significant, Chi-Square Test is applied by R Studio (Using PLYR and MASS packages). According to the test, the null hypothesis offer non-dependent pair of variables. As the $\mathrm{p}$ value is above 0.05 significant level, null hypothesis cannot be rejected. For the $\mathrm{p}$ values below the 0.05 , null hypothesis is rejected. Results reveal that some couple of variables is dependent to each other, for instance; visually and hearing impaired people, or visually impaired and walking with disabilities.

\subsection{Categories of Website Content}

Corporate website content results indicate specific categories as; additional services and products, declaration of will, discount, donation, education, employment, events, improved physical conditions, projects, service conditions and sports. Each of the categories is evaluated separately.

\subsubsection{Additional Services and Products}

Some of the additional services provided for disabled individuals are emphasized in Table 3. Only the products or services actualized are evaluated under this category. As being the most frequent service, transportation of people with disabilities is an opportunity mostly provided by airlines.

Table 3: Content Related to Additional Services and Products

\begin{tabular}{lccc}
\hline Content & $\begin{array}{c}\text { Target } \\
\text { Group* }\end{array}$ & $\begin{array}{c}\text { Service (S) / } \\
\text { Product (P) }\end{array}$ & $\begin{array}{c}\text { Frequency } \\
\text { of item }\end{array}$ \\
\hline Transportation for free of charge & MI, HI, VI & S & 6 \\
\hline Giving information about product/services & VI, HI & P, S & 3 \\
\hline Services in general term & HI, SI & P & 2 \\
\hline Visual call center & VI & S & 2 \\
\hline Additional rights in case of service failure & All & S & 1 \\
\hline Audible library & VI & S & 1 \\
\hline $\begin{array}{l}\text { Emergency plans for people with } \\
\text { disabilities }\end{array}$ & All & $\mathrm{S}$ & 1 \\
\hline Films having sign language subtitles & HI & S & 1 \\
\hline $\begin{array}{l}\text { Guiding in transformation and baggage } \\
\text { claim }\end{array}$ & VI & S & 1 \\
\hline Manufacturing disability friendly products & VI, HI, MI & P & 1 \\
\hline Voiced bill & VI & S & 1 \\
\hline Voiced contract & VI & S & 1 \\
\hline
\end{tabular}

*Speaking impaired=SI, Walking impaired=WI, Visually Impaired=VI, Hearing Impaired=HI, Physically Impaired=PI, Mentally Impaired=MI 


\subsubsection{Declaration of Will}

There are 15 firms declaring the will to act for people with disabilities in their websites, including future plans and ethical issues. As seen in Table 4, the most quoted subject is declaration of non-discrimination and giving equal rights to employees regardless of their gender, ethnicity and physical conditions.

Table 4: Content Related to Declaration of Will and Frequencies

\begin{tabular}{lc}
\hline Content & $\begin{array}{c}\text { Freq. of } \\
\text { item }\end{array}$ \\
\hline Disabled or abled individuals should have equal rights without discrimination & 6 \\
\hline Increase service/product quality of disabled & 4 \\
\hline Providing education for people with disabilities & 3 \\
\hline Disability friendly offices/places & 2 \\
\hline Project development & 2 \\
\hline Providing career development opportunities & 2 \\
\hline Support federation/association related to people with disability & 2 \\
\hline Being a member of federation/association related to people with disability & 1 \\
\hline
\end{tabular}

\subsubsection{Discount}

Amongst 50 firms, $10 \%$ of the firms indicate disability related discount. One of aerial transportation firm offers discount both for the passenger with disability and the companion, while the other allows seat reservation free of charge. Two of telecommunication firms offer discounts in services, also some services are given free of charge for customers with disabilities and for the relatives of these customers. On the other hand, a firm serving in production and distribution of petroleum and derivatives offers discount for the people with disabilities who are a member of disability association. However, for one firm discount is not valid for promotion tickets and for another firm, discounted fares are applied to at least $40 \%$ disabled people.

\subsubsection{Donation}

Out of 50 firms, 16 of them have donations related with disabilities and donations mainly take place by providing various kinds of wheelchairs, currency amounts, support for projects and sponsorships as seen in Table 5. 
Table 5: Donations Related to Disability

\begin{tabular}{|c|c|c|c|}
\hline Subject to Donation & Target Group & $\begin{array}{l}\text { Freq. } \\
\text { of item }\end{array}$ & Extent of Funding \\
\hline Several purposes & Associations & 5 & $\begin{array}{l}\text { Donation is collected with } \\
\text { message, } \\
\text { Amount of } \$ 4500 \text { aptly, } \\
\text { Notebook for students, } \\
\text { Transportation vehicle, } \\
\text { Not specified for other cases. }\end{array}$ \\
\hline Wheelchair & $\begin{array}{l}\text { Walking with } \\
\text { disabilities }\end{array}$ & 5 & $\begin{array}{l}\text { Number or type of wheelchairs } \\
\text { specified }\end{array}$ \\
\hline $\begin{array}{l}\text { Support for projects } \\
\text { or workshops of other } \\
\text { associations }\end{array}$ & $\begin{array}{l}\text { Target group of } \\
\text { the projects or } \\
\text { workshops }\end{array}$ & 4 & $\begin{array}{l}\text { Active participation of employees } \\
\text { to process } \\
\text { Amount of } \$ 3000 \text { to a project about } \\
\text { disability communication } \\
\text { For other cases, sponsorship }\end{array}$ \\
\hline Bicycle & HI students & 1 & Not specified \\
\hline $\begin{array}{l}\text { Distribution of income } \\
\text { from olive trees }\end{array}$ & All & 1 & Income of harvest \\
\hline $\begin{array}{l}\text { Handmade products of } \\
\text { disabled kids }\end{array}$ & All & 1 & Revenue from sales \\
\hline $\begin{array}{l}\text { Sponsoring theatre } \\
\text { plays about disabilities }\end{array}$ & Theatre & 1 & Not specified \\
\hline Supporting education & Disabled girls & 1 & Not specified \\
\hline
\end{tabular}

\subsubsection{Education}

Education related data in corporate websites covers educating employees and people with disabilities as seen in Table 6.16 of the firm's websites include education and disability related content. For some cases, education takes place in a project, which is also discussed under the category "project related content". 
Table 6: Education Related Content and Frequencies

\begin{tabular}{|c|c|c|}
\hline Issue & Target Group & $\begin{array}{l}\text { Freq. } \\
\text { of item }\end{array}$ \\
\hline $\begin{array}{l}\text { Infrastructure development/investment of a } \\
\text { school/class }\end{array}$ & People with disabilities & 5 \\
\hline Proper approach to people with disabilities & Employees & 4 \\
\hline Audible library & People with disabilities (VI) & 3 \\
\hline Sign language trainee training & People with disabilities (HI) & 2 \\
\hline $\begin{array}{l}\text { Occupational training to increase } \\
\text { employment }\end{array}$ & People with disabilities & 2 \\
\hline Training of English language & People with disabilities (VI) & 2 \\
\hline Android/computer training & People with disabilities (VI, MI) & 2 \\
\hline $\begin{array}{l}\text { Rising awareness about people with } \\
\text { disabilities }\end{array}$ & Employees & 2 \\
\hline Sign language training & Employees & 2 \\
\hline Total quality and motivation education & People with disabilities & 1 \\
\hline Orientation for newly-hired & People with disabilities & 1 \\
\hline Training for less-seeing kids (project) & People with disabilities (VI) & 1 \\
\hline Photography training & People with disabilities (PI) & 1 \\
\hline Education about various topics (as service) & People with disabilities (HI) & 1 \\
\hline $\begin{array}{l}\text { Education for families having hearing } \\
\text { impaired kids }\end{array}$ & $\begin{array}{l}\text { Relatives of people with disability } \\
\text { (HI) }\end{array}$ & 1 \\
\hline $\begin{array}{l}\text { Education in general purpose (counting, } \\
\text { shapes, calculation, colors etc.) }\end{array}$ & 3-14 year old with disability (MI) & 1 \\
\hline $\begin{array}{l}\text { Education material related to } \\
\text { communicating kids with disabilities }\end{array}$ & All & 1 \\
\hline
\end{tabular}

As seen in Table 6, content related to education mostly targets people with disabilities, though one of the most mentioned education is given to the employees with the purpose of increasing the awareness and improving the manner.

\subsubsection{Employment}

Out of 50 firms, 17 of them have information about employment of disabled in their main websites. Firms provide employment opportunities, hiring information, give the number of disabled personnel working in the firm, support the disabled for joining to workforce, job opportunities for the disabled youth at home, penalty information due to the lack of disabled employment, rewards gained due to high disables employment, publication of disabled staff 
employment evaluation results and sharing of exam questions. In addition, the applicant's disability ratio is asked in job application forms. For instance, one expression mentioned in the job posting is "Not being mentally or physically disabled that can prevent to do their duties". Interestingly, in one firm, one day military service training information is given to disabled personnel by the human resources department. In scope of disability week, 54 disabled employees working in one factory performed their one day military service with cooperation of one commandership. Additionally, there are several rewards related with employment of disabled individuals such as; being the company having the most employees with disability, employing disabled in employment surplus, valuing a diverse workforce and awareness in workforce, social responsibility and employment support.

\subsubsection{Events}

Such as projects, events are also discussed under different categories. To summarize, events are related to participating in food workshops, running marathon, plant seedling, watching sports on live, going to auto show, having picnic with the disabled people. Besides celebrating World Disabled Day, participating in the theatre or concert of people with disabilities, visiting them at school or some other locations related to people with disabilities, attending events that increase the awareness about people with disabilities, for instance, by playing games in the dark.

Considering the events related to art, 3 of the firms claim to support or participate in theatre performances of people with disabilities. Apart from that, marbling art training and audible painting exhibition are other events related to art.

\subsubsection{Improved Physical Conditions}

One fifth of the firms try to improve the physical conditions of disabled people in various ways. Firms mainly mentioned restrooms, elevators, Braille alphabet in warning plates, ramps in parking lots, technological devices etc. Some of the interesting developments for the disables are expressed in Table 7.

Table 7: Content Related to Improving Physical Conditions

\begin{tabular}{llc}
\hline Content & \multicolumn{1}{c}{ Target Group } & $\begin{array}{c}\text { Freq. } \\
\text { of item }\end{array}$ \\
\hline Improvements in restroom, social facilities & Employee, Customer & 4 \\
\hline Improvements in service desk & Customer & 4 \\
\hline Disability friendly school & Other (Students) & 3 \\
\hline Parking lot & Customer, Employee & 2 \\
\hline Audible warnings in automatic doors & Customer, Employee & 1 \\
\hline Audible warnings inside the service oriented company & Customer, VI & 1 \\
\hline Certification for disability friendly facilities & Customer, Employee & 1 \\
\hline Disability friendly elevators & Customer, Employee & 1 \\
\hline
\end{tabular}


Table 7 continued

\begin{tabular}{lll}
\hline Elevator & Employee, WD & 1 \\
\hline Funding for disabled friendly hotel rooms & Customer & 1 \\
\hline Improved transportation facilities, vehicles to service point & Customer & 1 \\
\hline Improvements in product & Customer, MI & 1 \\
\hline Rest area for trained dogs & Customer, VI & 1 \\
\hline Telephone clubs for the use of people with disability & Customer & 1 \\
\hline Warning plates with Braille alphabet & Employee, HI & 1 \\
\hline Voiced warning system & Employee, VI & 1 \\
\hline
\end{tabular}

\subsubsection{Projects}

This category is composed of various issues and some of the projects are also indicated under other categories. Amongst 50,16 of the firms indicate projects in their corporate websites. Projects are related to several issues as shown in Table 8.

Table 8: Contents Related to Projects with Frequencies

\begin{tabular}{lc}
\hline Content & Freq. of item \\
\hline Improvements in services & 6 \\
\hline Collecting plastic caps and lids to transform them into wheelchairs & 5 \\
\hline Infrastructural development of several places & 5 \\
\hline Employment of people with disabilities & 2 \\
\hline Some trainings of people with disabilities & 2 \\
\hline Attending social events with people with disabilities & 1 \\
\hline Audible library & 1 \\
\hline Body with a person with disability & 1 \\
\hline Distributing beneficial tools except wheelchair & 1 \\
\hline Sharing a success story of a person with disability & 1 \\
\hline Some trainings of employees to increase their awareness & 1 \\
\hline
\end{tabular}

\subsubsection{Service Conditions}

Service conditions are only indicated in the aerial transportation firms (serving in travel and transportation industry), in order to define the conditions to be a passenger. Accordingly, only three firms indicated the conditions to be a passenger. Common conditions indicated by the firms are;

- Types of disabilities (requirements) not to fly without a companion,

- Cases to be traveling only with companion 
- Necessary document to be carried with the passenger

- Informing employees about the conditions of the passenger with disabilities, what kind of information to be given

- Restrictions in seat positions for passengers with disabilities

- Conditions for the passengers traveling with a companion dog

- Conditions for the companion passenger

- Definitions of handicapped or disabled person

\subsubsection{Sports}

Only 9 firms' corporate websites mention about disability and sports, where 6 of them financially support various sport groups composed of people with disabilities. 2 of the groups, teams are established by the firms. Moreover, while one of the firms improves the infrastructure of the stand for sports spectators, the other firm supports the education of disabled sportsman.

\section{Evaluation of Findings}

In this study, disability related content is systematically examined in the corporate websites of top 50 Fortune companies with high income levels where the vast majority of the firms are situated in Istanbul and Ankara. Results reveal that content related to the type of disability in websites commonly refers to the general concept of disability, visually impaired and walking with disabilities respectively. When the data of disability types are analyzed with Chi-square test, some of the types are evaluated to be in relation; which means that a firm indicating visual impairment, generally indicates hearing impairment.

Most frequent content under the category of education is related to infrastructure and employee training. Infrastructure development of a school/class, is an indirect support though highly preferred by $10 \%$ of the firms. Training of employees about proper approach to people with disabilities is also favored by $8 \%$ of the firms.

Sports related content is low since $18 \%$ of the firms indicate disability related sports. Two of the teams composed of people with disabilities, are established by the firms. Improving the infrastructure of various areas and training of disabled sportsman are other issues.

Since $41 \%$ of the firm's corporate websites indicate disability related projects; these are mostly related to other items discussed under several categories. The most frequent project is recognized to be firm specific which is about the improvements in services. The next most frequent recurring concepts, which are about collecting plastic lids for wheelchairs and infrastructural development, are more socially inclusive, not related to the commercial purposes.

Firms also report that they participate in different activities with disabled people. In some of them, people with disabilities are audiences, while some of them are participative. Besides the activities with disabled people, for some events, participants are employees and the event is about to increase the awareness about people with disabilities for instance, by playing games in the dark. 
Although some firms did not take the necessary action, they emphasize that they will implement their strategies in the topic of disability soon. This kind of information is indicated under the category of "declaration of will". Most frequent discourse is about equal rights and a non-discriminatory approach. The second most frequent discourse is about the intention of developing the specifications of products or services.

Among the revealed categories, only "service conditions" is recognized to be sector specific, which is indicated by aerial transportation firms. Service conditions is about defining the type of disability, necessary documents in the airport, conditions to fly with a companion, kind of information given to the firm etc. This sector specific differentiation may be related to safety issues and the provision of the services to transnational areas.

Discounts are also part of the website content as $10 \%$ of the firms indicate people with disability specific discounts. As indicated above, aerial transportation firms are the only group related to companion. As a result of this, one of the aerial transportation firms offers discount both for the passenger with disability and the companion. Other discounts are related to products, services for people with disabilities or for the members of disability association.

The corporate firms have several additional services especially for visually impaired, hearing impaired, speaking impaired and mentally impaired. Technological services in various versions exist such as visual call center, voiced books, voiced bill services and agreements, voiced information about product and services via messages, newly designed vehicles. Another interesting situation is that one petro-chemistry firm produces medical products that make disabled life easier such as implants, hearing devices, plastic capsules, and artificial corneas used in heart surgery and prosthesis-orthopedic products. Improvements related with these types of innovative products for people with disabilities will be pivotal in the health and medical industry.

In terms of improving the physical conditions, firms mainly mentioned restrooms, elevators, Braille alphabet in warning plates, ramps in parking lots, technological devices, bettering conditions of buildings, airports etc. Moreover, out of 50 firms, 16 of them have donations related with disabilities. A couple of firms mentioned the amount of their donations. Some generally donate various types of wheelchairs after their collection of plastic lids, home appliances. Some prefer to donate as sponsorship, presentation of social activities within the society, establishment of therapy and activity rooms.

Only $34 \%$ of the firms have basic information about the employment situation of disabled in their corporate websites. Firms put several efforts for disabled stakeholders such as providing employment opportunities, hiring information, supporting them for joining to workforce, providing job opportunities for disabled youth at homes, penalty information for the firms due to lack of disabled employment, rewards gained due to high disabled employment, publication of disabled staff employment evaluation results and sharing of exam questions. Interestingly, in one firm, one day military service training information is given to disabled personnel by the human resources department. The earned rewards related with the employment of disabled individuals might lead the corporate firms concentrate on this topic more than the past. 
In overall findings of research, there are various promising efforts of top corporate Fortune firms in Turkey towards the activities of people with disabilities and corporate firms approach the concept of disability from different perspectives and dimensions. The awareness of this topic will fundamentally increase the level of understanding about various dimensions of disability and social consciousness in corporate firms.

\section{Conclusion and Implications}

The main purpose of this exploratory research is to understand the role of institutionalization and stakeholder theory on high visual and high profit Fortune firms in Turkey, related to the disability disclosure. Accordingly, isomorphism is assumed to be the issue in disability related content of corporate websites by finding out and analyzing what type of activities or applications for disabled stakeholders exist in the top 50 Fortune firm's corporate websites in Turkey.

The results reveal further questions in this area while keeping its originality through the items below;

- Besides the similar theoretical basis in literature, this research mainly focuses on the disability content through corporate websites taking into consideration of the stakeholder theory and isomorphism.

- From the perspective of isomorphism, the research is enlightened by how much the firms become similar in their disability related content and also how much they differ in their activities within the concept of disability.

- Categorization of different types of disability and analysis of their frequencies are actualized.

- There is no any other study aiming specifically at disability in the website contents of Fortune firms in Turkey from the mentioned theoretical standpoint.

- The study helps increase public awareness of disability related efforts, considering the increase in number of disabled students between 2002 and 2015 and conversely the low increase in number of schools for people with disabilities since 2013 in Turkey.

In line with the purpose and originality of this research, Fortune firms' corporate websites are analyzed based on the disability related content. Though, $22 \%$ of the corporate websites do not include information on disability. It is observed that the content of websites indicate similarities especially for some sectors. In production and distribution of petroleum and derivative sector, one of the firms initiated improvement in infrastructure and this increased the reputation of the firms among the people with disabilities. Other firms in this sector are influenced by these efforts and also initiated improvements in other firms.

Firms in travel and transportation services are the only Fortune firms, explaining the service conditions. This can be related to the international transportation obligations, or competitive environment, which indicates that environmental conditions may play a role in shaping the procedures. Similarly, the firms taking place in the telecommunication industry have developed similar campaigns and these campaigns are recognized to be related to customers with disabilities. This isomorphic approach may be a result of competition and interdependency 
within these sectors. On the other hand, according to Chi-square test results, it is apparent that some disability related groups are evaluated together, which indicates an inter-sectoral isomorphism.

This similarity between and within the industries can be associated with the institutionalization approach asserted by DiMaggio and Powell (1983). Greenwood and Hinings (1996) expressed that isomorphism in the institutionalization process becomes dominant for the industries. However, on the contrary, it is recognized that there are more differences than the similarities. Rare contents such as art related events or sports, types of donations indicate the differences of firms. These differences may point out that there might be a different viewpoint in the institutionalization process or no single or systematic corporate perspective about the disability approach exists. This basically means that the disability view varies among the firms and firm policies about disability should be considered inventively. Besides, Suarez (2003) discusses the similarity and isomorphism through a philosophic perspective and indicates that "no theory that attempts to reduce scientific representation to similarity or isomorphism will succeed". This opposite perspective might also be valuable for this case.

As a result of this research shaped by institutionalization, stakeholder and legitimacy theories, some similarities are recognized. But it is seen that Fortune firms in view, have similarities only in some specific industries. Therefore, the results do not fully support the existence of isomorphism. There may be different explanations for this outcome; one of these may be related to the low maturation of the disability related policies or the low awareness of public may be resulting in lack of public pressure. Besides, it may be related to the disruptions in law enforcement, since some of the firms do not even employ the obliged number of disabilities.

Based on the uniqueness of this research due to the factors stated above, this research sheds light on the efforts put on for the disabilities by the top fifty firms in Turkey and will open up perspectives of other firms, researchers and practitioners.

\section{Limitations and Future Research}

The study comes with several limitations. The scope of the study consists of top fifty Fortune firms in which only the matter of disabilities is analyzed and evaluated. Long time is allocated for consideration of analysis related to time constraints and difficulty in reaching specific data about disabled. Additionally, the time dependent change of website contents also created hassles in searching for the required data. Website contents are analyzed regardless of when they are published since the purpose of study is to understand the perspective of firms but not to evaluate the change in the perspectives. So that the research via Google search engine is considered to be appropriate.

For future research, some other firms in various industries can also be studied qualitatively and quantitatively. The categorizations in this research may help researchers and practitioners use in their other studies related with disabilities and increase much more awareness in corporate websites. Considering institutionalization, stakeholder and legitimacy theories on the basis of sectoral measurements, the outcomes of this exploratory research will deepen the analysis of future studies. In line with the situation in Turkey, the increase in the spending of allowances for people with disabilities and the increase in employment of disabled are seen as pivotal 
developments in the region. The comparison between the previous developments related with disability in Fortune firms and the current situation can also be analyzed.

\section{References}

Bell, D., \& Heitmueller, A. (2009). The disability discrimination act in the UK: Helping or hindering employment among the disabled? Journal of Health Economics, 28 (2), 465 480.

Ball, P., Monaco, G., Schmeling, J., Schartz, H., \& Blanck, P. (2005). Disability as diversity in fortune 100 companies. Behavioral Sciences and the Law, 23, 97-121.

Blair, M. M. (2004). The great pension grab: Comments on Richard Ippolito, bankruptcy and workers. Washington University Law Quarterly, 82, 1305.

Branco, M. C., \& Rodrigues, L. L. (2006). Communication of corporate social responsibility by Portuguese banks: A legitimacy theory perspective. Corporate Communications: An International Journal, 11 (3), 232-248.

Briggs, B. S., \& Saas, C. (2016). Websites and mobile applications: Do they comply with title III of the Americans with disabilities act? Florida Bar Journal, September 1.

Bundon, A., \& Clarke, L. H. (2015). Unless you go online you are on your own: Blogging as a bridge in para-sport. Disability \& Society, 30 (2), 185-198.

Callison, C. (2003). Media relations and the internet: How Fortune 500 company web sites assist journalists in news gathering. Public Relations Review, 29, 29-41.

Deephouse, D. L. (1996). Does isomorphism legitimate? The Academy of Management Journal, 39 (4), 1024-1039.

De Villiers,C.,\& Alexander,D.(2014). The institutionalization of corporate social responsibility reporting. The British Accounting Review, 46 (2), 198-212.

DiMaggio, P. J., \& Powell, W. W. (1983). The iron cage revisited: Institutional isomorphism and collective rationality in organizational fields. American Sociology Review, 147-160.

Ellis, K., \& Kent, M. (2011). Disability and new media. New York: Routledge.

Engelliler Hakkında Kanun (2005). Kanun No: 5378, Resmi Gazete, 5 (44).

Frank, J. (2008, January). Web accessibility for the blind: Corporate social responsibility or litigation avoidance? Proceedings of the 41st Hawaii International Conference on Systems Science, USA.

Freeman, R. E. (1984). Strategic management, a stakeholder approach. Pitman, Boston.

Gabel, S. L., Reid, D., Pearson, H., Ruiz, L., \& Hume-Dawson, R. (2016). Disability and diversity on CSU websites: A critical discourse study. Journal of Diversity in Higher Education, 9 (1), 64-80.

General Directorate of Services for People with Disabilities and Elderly People (2016). Engelli ve yaşl bireylere ilişkin istatistiki bilgiler, engelli ve yaşl hizmetleri genel müdürlüğ̈̈ istatistik bülteni. Retrieved February 03, 2017, from http://eyh.aile.gov.tr/ data/56179f30369dc5726c063e73/B\%C3\%BClten_Temmuz2016.pdf 
Goggin, G., \& Newell, C. (2003). Digital disability: The social construction of disability in new media. Amyland: Rowman and Littlefield.

Greenwood, R., \& Hinings, C. R. (1996). Understanding radical organizational change: Bridging together the old and the new institutionalism. Academy of Management Review, 21 (4), 1022-1054.

Gutierrez, C. F., \& Windsor, J. C. (2005). An evaluation of Fortune 500 company home pages for disability-access. International Journal of Electronic Business, 3 (2), 137-153.

Harrison, J. S., \& Freeman, R. E. (1999). Stakeholders, social responsibility and performance. Academy of Management Journal, 42 (5), 479-485.

Huang,Z., \& Cappel, J. J. (2012). A comparative study of website usability practices of Fortune 500 versus INC. 500 companies. Information Systems Management, 29 (2).

İşkur - Turkish Labor Agency (2015). 2015 yılında engellilerin engel gruplarına göre dă̆ılımı. Retrieved February 02, 2017, from http.//www.iskur.gov.tr/kurumsalbilgi/ istatistikler.aspx

Jones, S. L., \& DeGrow, D. (2011). Fortune 500 homepages: Design trends. IEEE Transactions on Professional Communication, 54 (1).

Jones, S. L. (2015). A re-examination of Fortune 500 homepage design practices. IEEE Transactions on Professional Communication, 58 (1).

Kim, S., Park, J. H., \& Wertz, E. K. (2010a). Expectation gaps between stakeholders and webbased corporate public relations efforts: Focusing on Fortune 500 corporate web sites. Public Relations Review, 36 (3), 215-221.

Kim, D., Nam, Y., \& Kang, S. (2010). An analysis of corporate environmental responsibility on the global corporate web sites and their dialogic principles. Public Relations Review, 36 (3), 285-288.

Knuz, M., Ratliff, J. M., Blankenbuehler, M., \& Bard, T. (2014). A preliminary examination of sustainable disclosures on Fortune 500 company websites. Academy of Strategic Management Journal, 13 (1), 1.

Lee, I. (2005). E-recruiting: Categories and analysis of Fortune 100 career web sites. In T. Torres-Coronas, \& M. Arias-Oliva (Eds.), e-Human resources management: Managing knowledge people (pp. 86-100). Hershey, PA: IGI Global.

Levy, J. M., Jessop, D. J., Rimmerman, A., \& Levy, P. H. (1992). Attitudes of Fortune 500 corporate executives toward the employability of persons with severe disabilities: A national study. Mental Retardation, 30 (2), 67-75.

Liu, C., \& Arnett, P. K. (2002). Raising a red flag on global WWW privacy policies. Journal of Computer Information Systems, 43 (1), 117-127.

Liu, C., Arnett, K. P., Capella, L., \& Beauty, B. (1997). Web sites of the Fortune 500 companies: Facing customers through home pages. Information and Management, 31 (1), 335-345.

Moore, M. (2013). Disability, global conflicts and crises. Disability \& Society, 28 (6), 741-743.

Pate, J. R., Ruihley, B. J., \& Mirabito, T. (2014). Displaying disability: A content analysis of person-first language on NCAA Bowl Championship Series college athletic department websites. Journal of Applied Sport Management, 6 (1). 
Patten, D. M. (1991). Exposure, legitimacy, and social disclosure. Journal of Accounting and Public Policy, 10, 297-308.

Perry, M.L., \& Bodkin,C.D. (2002). Fortune 500 manufacturer web sites: Innovative marketing strategies of cyberbrochures? Journal of Promotion Management, 31 (2), 133-144.

Podlas, K. (2015). Website accessibility and the Americans with disabilities act. Journal of Internet Law, 19 (5), 3-16.

Quevedo-Puente, E., Fuente-Sabate, J. M., \& Delgado-Garcia, J. B. (2007). Corporate social performance and corporate reputation: Two interwoven perspectives. Corporate Reputation Review, 10 (1), 60-72.

Republic of Turkey Ministry of Family and Social Policy (2014). 2002-2013 development and disability in Turkey: A report of the last decade. Retrieved Feb. 13, 2017, from http://eyh.aile.gov.tr/data/549d6891369dc5abbc92cc7e/bm_kitapcigi_ingilizce_ tumu_23.05.2014.pdf

Romano, N. C. (2002). Customer relationship management for the web-access challenged: Inaccessibility of Fortune 250 business web sites. International Journal of Electronic Commerce, 7 (2), 81-117.

Seale, J. K. (2007). Strategies for supporting the online publishing activities of adults with learning difficulties. Disability \& Society, 22 (2), 173-186.

Suarez, M. (2003). Scientific representation: against similarity and isomorphism. International Studies in the Philosophy of Science, 17 (3), 225-244.

Suchman, M. C. (1995). Managing legitimacy: Strategic and institutional approaches. Academy of Management Review, 20, 571-610.

Tas, S., \& Bozyaka, G. (2012). Avrupa Birliğine uyum sürecinde Türkiye'de uygulanan istihdam politikaları. Kahramanmaraş Sütçü Imam Üniversitesi IIBF Dergisi, 2 (1), 151-176.

TUIK - Turkish Statistical Institute (2015). Dünya nüfus günü, haber bülteni. Retrieved February 04, 2017, from http://www.tuik.gov.tr/PreHaberBultenleri.do?id=18617

USDL - United States Department of Labor (n.d.). Americans with disabilities act. Retrieved November 02, 2016, from https://www.dol.gov/general/topic/disability/ada

Web Accessibility Initiative - WAI (2017). Web accessibility initiative. Retrieved January 07 , 2017, from https://www.w3.org/WAI/

World Health Organization \& The World Bank (2011). World report on disability. Retrieved November 21, 2016, from http://www.who.int/disabilities/world_report/2011/report. pdf.

Young, J., \& Foot, K. (2005). Corporate e-cruiting: The construction of work in Fortune 500 recruiting web sites. Journal of Computer-Mediated Communication, 11 (1), 44-71.

Zhao, J. J., Truell, A. D., \& Alexander, M. W. (2006). User-interface design characteristics of Fortune 500 B2C e-commerce sites and industry differences. Delta Pi Epsilon Journal, 48 (1), 43-55. 
